\title{
LONG-TERM PERFORMANCE OF CONTACTING CONCRETE AND SMECTITE CLAY IN DEEP DISPOSAL OF HIGHLY RADIOACTIVE WASTE
}

\author{
R. PUSCH \& T. YANG \\ Dept. of Civil, Environmental and Natural resources Eng., Luleå University of Technology, Luleå, Sweden.
}

\begin{abstract}
Disposal of highly radioactive waste (HLW) can be environmentally acceptable if radionuclides are kept isolated from the groundwater, which has inspired planners of repositories to work out multibarrier concepts that postulate defined functions of the host rock and engineering barriers. Assessment of the role of the host rock involves groundwater flow modelling and rock mechanical analysis, which are both highly speculative and ignore future changes in rock structure, stress conditions, and groundwater flow. This makes use of engineered barriers necessary and possible technical solutions for isolating containers with HLW by clay and concrete seals have been described in the literature. The present paper examines the performance and interaction of such seals in very deep boreholes with respect to chemical reactions and their impact on the sealing functions.
\end{abstract}

Keywords: cation exchange, clay, concrete, dissolution of clay minerals, interaction of smectite and cement.

\section{SCOPE}

One way of disposing highly radioactive spent reactor fuel is to place it in deep boreholes (Fig. 1). The concept is referred to here as VDH and has clay as major sealing material [1]. Concrete is cast where the holes intersect water-bearing fracture zones. The paper deals with the chemical interaction of the two materials and its impact on their sealing potentials.

\section{ENVIRONMENTAL CONDITIONS}

The VDH concept implies construction under water that is very salty, heavy and Ca-dominated below about 2,000 $\mathrm{m}$ depth. Its density makes it stay at depth, which hence reduces the demand for using long-lasting canisters and embedding buffer clay. There are no hydraulic gradients and most of the construction work, including boring of the 4,000 m deep holes with about $800 \mathrm{~mm}$ diameter, can be made by utilizing techniques developed by the off-shore gas and oil industry. Certain difficulties are expected in the construction of the deep holes where they pass through fracture zones, but the deep-drilling industry has good hope to manage. Engineered barriers, clay and concrete, placed in them for guaranteeing effective sealing of the holes must perform acceptably for long periods of time, which is the matter focused on in the present paper.

\subsection{Design and construction}

The constant diameter of the deep holes considered here is $800 \mathrm{~mm}$. They are made by boreheads with bits, and reamers rotated in drilling fluid of smectite clay mud with a density of at 

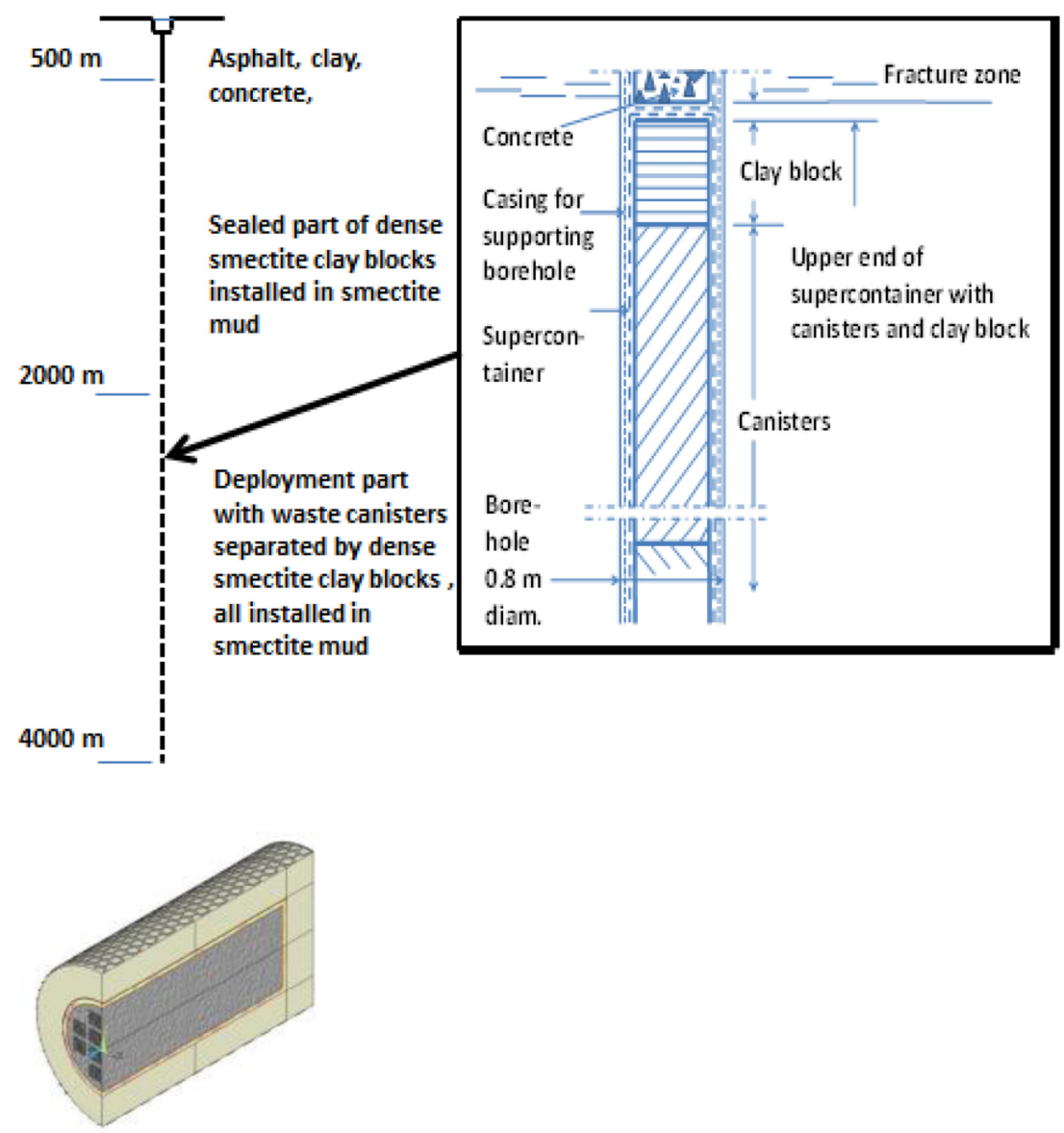

Figure 1: VDH concept. Supercontainers with clay-embedded HLW canisters (below) are placed in the lower $2000 \mathrm{~m}$ part. In the upper part the containers are filled only with very dense smectite clay.

least $1,150 \mathrm{~kg} / \mathrm{m}^{3}$, cyclically pumped down through the borehead and cleaned and recharged when moved back to the ground surface. It serves to bring up boring debris from the boreholes, to stabilize the rock, and to cool the borehead. Such mud also fills the holes in the placement of seals and waste and prevents the dense clay seals to expand out through the confining perforated supercontainers too quickly since this would cause too high frictional resistance [2, 3]. For preventing coagulation of the smectite mud, which should be in sodium form, the boreholes are filled with freshwater that is pressed up by mud injected from below before installation of supercontainers with dense clay and clay-lined waste canisters starts.

The criterion that no supercontainers shall be installed where the holes intersect waterbearing fracture zones (cf. Fig. 2) would mean that these will play no role in transporting radionuclides while clay placed in such positions would be eroded and dispersed. For further reducing the risk of erosion and loss of clay particles from the clay seals in adjacent supercontainers, with or without HLW canisters, the fracture zones should be grouted with erosion-resistant fine-granular cement compounds. A recommended grout recipe has 


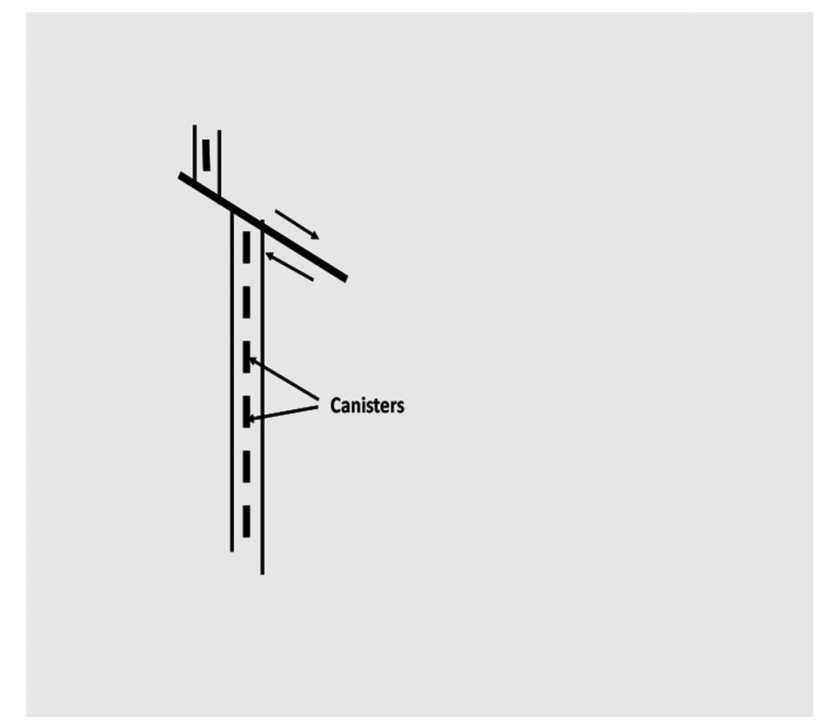

Figure 2: Displacement of series of supercontainers with waste containers by seismically or tectonically generated shearing of a major discontinuity.

$6 \%-10 \%$ low-pH cement and aggregate of very fine, well graded quartzite mixed with silica flour $[4,5]$. Where concrete is to be cast the VDH holes are preferably reamed for anchoring the thereby widened concrete seals.

\subsection{Waste and seal placement}

At present, the following techniques and materials are proposed:

Uppermost 0-50 m; on site-compacted sand/gravel, dry density $>1,800 \mathrm{~kg} / \mathrm{m}^{3}$,

50-100 m: Varved block layers of dense smectitic clay and low-pH concrete with talc as a fluidizer instead of organic substances since they can form organic colloids with a potential of transporting possibly released radionuclides,

100-2,000 m: Sets of connected supercontainers (cf. Fig. 3) filled with highly compacted blocks of smectite-rich clay forming up to $18 \mathrm{~m}$ long units inserted in smetite-rich salt-free mud with a density of at least $1,150 \mathrm{~kg} / \mathrm{m}^{3}$ (in air),

2,000-4,000 m: Sets of connected supercontainers of titanium or Navy Bronze taken here as an alloy of $90 \%$ copper and $10 \%$ zinc. The diameter is around $700 \mathrm{~mm}$ allowing canister diameters to be about $500 \mathrm{~mm}$ with $3,050 \mathrm{~mm}$ length and equipping them with 50-100 mm compacted smectitic clay liner (cf. Fig. 2). Each supercontainer can have two canisters of copper, Navy Bronze $(90 \% \mathrm{Cu}, 10 \%$ zinc) or titanium with spent reactor fuel rods cast in concrete. The canisters are separated in the supercontainers by $1 \mathrm{~m}$ long blocks of very dense smectite-rich clay and separated from the ends of the containers by blocks of the same type. The supercontainers have a diameter of about $700 \mathrm{~mm}$ and a length of about $9 \mathrm{~m}$ (cf. Fig. 1).

In practice, there must be a "respect distance" of 10-50 $\mathrm{m}$ from the supercontainer nearest to the discontinuity, depending on its content. 
The following criteria shall apply:

- The salt-free deployment mud surrounding the supercontainers in the installation phase must remain coherent, meaning that no gaps are allowed between canister sets or mud in the installation phase at the expected temperature of up to about $150^{\circ} \mathrm{C}$,

- The supercontainers must be at the planned depth before stiffening of the mud caused by the temperature and consolidating pressure from the dense clay in them becomes too strong $[2,3]$. The required time is estimated at 8 hours for each set of supercontainers,

- The seals formed by consolidated mud and expanded dense buffer clay in the holes down to $2 \mathrm{~km}$ depth must remain coherent and be tighter than the surrounding rock at the expected temperature $20^{\circ} \mathrm{C}-70^{\circ} \mathrm{C}$,

- Casting of concrete where the holes intersect water-bearing fracture zones causes interruption of the installation of supercontainers by one or a few days during which clay mud must fill the not yet backfilled part of the respective hole.

\section{STABILITY OF CONCRETE AND CLAY COMPONENTS}

\subsection{Reactions between concrete and clay}

A simple model can be used to illustrate the general process of chemical degradation in water of concrete with Portland cement [6]:

1. $\mathrm{Ca}(\mathrm{OH})_{2}$ is assumed to be dissolved layer-wise from the original clay/concrete interface and inwards in the concrete,

2. The Ca concentration in the clay is initially zero,

3. The solid cement matrix contains $C \mathrm{kmol} \mathrm{Ca} / \mathrm{m}^{3}$,

4. The Ca concentration in the concrete porewater is constant and equal to $c \mathrm{kmol} \mathrm{Ca} / \mathrm{m}^{3}$ in the unlatched concrete

5. $c$, which is determined by the solubility of calcium in equilibrium with calcium silicate hydrates, is taken as $2 \mathrm{E}-3 \mathrm{kmol} \mathrm{Ca} / \mathrm{m}^{3}$.

Applying diffusion theory, we get the quantity $M_{t}$ that migrates into the clay at time $t$ after onset of diffusion under the diffusion coefficient $\mathrm{D}$ :

$$
M_{t}=2 c(\mathrm{Dt} / \pi)^{1 / 2}
$$

Which equals the calcium content within the distance $x$ from the interface, hence yielding:

$$
M t=C x
$$

Combination of eqns (1) and (2) gives:

$$
\mathrm{D}=\pi / 4(\mathrm{C} / \mathrm{c})^{2} \mathrm{x}^{2} / \mathrm{t}
$$

Assuming $\mathrm{C}=10 \mathrm{kmol} \mathrm{Ca} / \mathrm{m}^{3}$ of the cement matrix and denoting by $x$ half the extension of the reacted shallow layer in the concrete we obtain for the diffusion coefficient $\mathrm{D}=6 \mathrm{E}-12 \mathrm{~m} / \mathrm{s}$, the depth in meters in the concrete to which Ca dissolution has occurred after a certain time in years is given in Table 1 [6].

The table shows that the concrete will be strongly depleted in calcium and mechanically weakened to about $0.1 \mathrm{~m}$ depth in 50 years and to $0.87 \mathrm{~m}$ depth in 500 years. After 500 years 
Table 1: Distance from clay/concrete interface to where the calcium concentration in the concrete has dropped to $5 \%$ and $50 \%$ of the concentration at the interface.

\begin{tabular}{lcc}
\hline Time, years & Front of $5 \%$ concentration, $m$ & Front of $50 \%$ concentration, $m$ \\
\hline 10 & 0.12 & 0.04 \\
50 & 0.27 & 0.10 \\
100 & 0.39 & 0.13 \\
500 & 0.87 & 0.30 \\
1,000 & 1.22 & 0.42 \\
\hline
\end{tabular}

a considerable part of meter-long concrete seals will have lost a significant part of their mechanical strength. At the rock contact the same degrading process will take place: depletion of calcium of the peripheral parts of the cylindrical plug and loss of this element by water flow or diffusion in the boring/disturbed zone that is a few millimeters thick. This excavationdisturbed zone serves as a path for possibly released radionuclides, but becomes partly sealed by clay mud and gels emanating from the dense clay in the supercontainers.

Smectite clay seals in contact with the concrete will undergo cation exchange to Ca that moves in from the degrading concrete to a depth of several centimeters from the clay/concrete contact already in a few years as verified by field experiments [4]. The cation exchange to calcium from originally sodium in the clay raises its hydraulic conductivity about one order of magnitude, thereby reducing its sealing ability. The content of smectite in the clay seals is important: if they contain only 25 or $50 \%$ of such clay minerals the microstructural coagulation will cause comprehensive increase in microstructural porosity and raise the conductivity by at least 4 and 2 times, respectively.

\subsection{Impact of temperature on concrete and smectite clay}

\subsubsection{Concrete}

In the upper, sealed part of the VDH the temperature will range from about $15^{\circ} \mathrm{C}$ to $60^{\circ} \mathrm{C}$ causing no heat-induced changes of concrete based on Portland cement or low-pH cement. They will both provide total tightness directly after installation. In the deployment part, extending from 2,000 to $4,000 \mathrm{~m}$ depth, the temperature will be up to $150^{\circ} \mathrm{C}$, and there is limited experience and proof of the chemical stability of Portland cement concrete under the hydrothermal conditions prevailing in this part.

For concrete with low-pH cement and talc as fluidizer ${ }^{1}$ recent tests of cement-poor concrete with quartzite aggregate have been made with the recorded changes in chemical composition indicated in Table 2, (cf. Pusch [5, 7]. It shows that the temperature in the tests running for 8 weeks has no obvious impact on the chemistry. Dissolution and precipitation processes took place with almost constant relative amounts of the respective elements up to $75^{\circ} \mathrm{C}$, which will prevail in the deepest part of the "sealed" zone in a VDH. For the deepest part of the deployment zone, with temperatures up to $150^{\circ} \mathrm{C}$, one would expect more obvious

\footnotetext{
${ }^{1}$ Organic fluidizers may be ruled out: they can produce organic colloids capable of transporting radionuclides
} 
Table 2: Change in chemical composition of talc concrete cured at different temperatures ${ }^{2}$.

\begin{tabular}{lcccccccc}
\hline Temperature & $\mathrm{CO}_{2}$ & $\mathrm{Na}_{2} \mathrm{O}$ & $\mathrm{MgO}$ & $\mathrm{Al}_{2} \mathrm{O}_{3}$ & $\mathrm{SiO}_{2}$ & $\mathrm{CaO}$ & $\mathrm{TiO}_{2}$ & $\mathrm{FeO}$ \\
\hline $20^{\circ} \mathrm{C}$ & 28,6 & 0,1 & 9,8 & 3,8 & 60,4 & 0,9 & 0,5 & 3,4 \\
$75^{\circ} \mathrm{C}$ & 21,7 & 0,1 & 19,0 & 2,3 & 54,0 & 1,2 & 0,2 & 5,3 \\
$150^{\circ} \mathrm{C}$ & 23,5 & 0,3 & 10,5 & 7,5 & 56,7 & 1,5 & n.d & n.d \\
\hline
\end{tabular}

changes than indicated in Table 2, but the variation in the original composition of the tested concrete makes prediction of the long-term function uncertain.

Talc concrete with w/c $=9.5$ and an aggregate/cement ratio of 12.8 has been investigated with respect to its strength properties after exposure to hydrothermal conditions under temperatures up to $150^{\circ} \mathrm{C}$ for simulating VDH conditions. Samples cured at room temperature for 28 days had a compressive strength of $2.6 \mathrm{MPa}$ and $4.5 \mathrm{MPa}$ after 45 days. At $75^{\circ} \mathrm{C}$ the compressive strength had increased to about $9 \mathrm{MPa}$ after 45 days and to the same level at $150^{\circ} \mathrm{C}$, indicating that the strengthening processes were complete already at $75^{\circ} \mathrm{C}$ and that this type of concrete has a potential of serving acceptably in deep repositories even during long periods of time. The hydraulic conductivity was about E- $8 \mathrm{~m} / \mathrm{s}$ for the sample cured at room temperature, about E- $9 \mathrm{~m} / \mathrm{s}$ for the $75^{\circ} \mathrm{C}$ sample and $\mathrm{E}-10 \mathrm{~m} / \mathrm{s}$ for the $150^{\circ} \mathrm{C}$ sample, indicating that cement gels grew with curing time and ultimately occupied large parts of the voids in the aggregate matrix.

\subsubsection{Clay}

Mineralogical changes and less good isolation potential are expected for smectite-rich VDH clay as illustrated by the XRD spectrum in Fig. 3. Montmorillonite, which is the primary candidate smectite candidate, is converted to (non-expansive) illite via mixed-layer smectite/ illite minerals or precipitated as such, and quartz is formed at a rate determined by temperature and access to potassium [8]. Cementation is caused by precipitation of neoformed quartz and illite (Fig. 4). Natural analogues from various parts of the world indicate that Tertiary and Ordovician bentonites exposed to about $130^{\circ} \mathrm{C}-160^{\circ} \mathrm{C}$ for a few thousand years have a significant part of their montmorillonite content preserved $[8,9]$, and this is expected to be the case also for the clay seals in VDH [5]. Most of them, with the possible exception of the superior Mg-bearing species saponite [10], will be more or less cemented by precipitation of silicious compounds, losing much of the initial ductility and expandability of smectite clays that are typical of smectites.

The chemical evolution of the clay depends on the temperature and salt concentration in the groundwater, the K-content in particular $[8,10]$ as well as on the interaction with the metal canisters, supercontainers, and borehole-stabilizing casings. Some minor exchange of the initially sorbed sodium ions by metal ions like copper emanating from them will take place, but $\mathrm{Ca}$, the dominant cation in strongly brackish KBS-3V groundwater and in very salt groundwater $(>10 \mathrm{~g} / \mathrm{l})$ in the deeper parts of a VDH, will control the microstructural constitution and thereby the physical properties.

Exposure of water-saturated montmorillonite-rich clay to strong gamma radiation and $90^{\circ} \mathrm{C}-135^{\circ} \mathrm{C}$ temperature has no obvious degrading impact, but speeds up dissolution and

\footnotetext{
${ }^{2}$ Analyses made by Institute for Geography and Geology. Ernst-Moritz-Arndt University, Greifswald, Germany.
} 


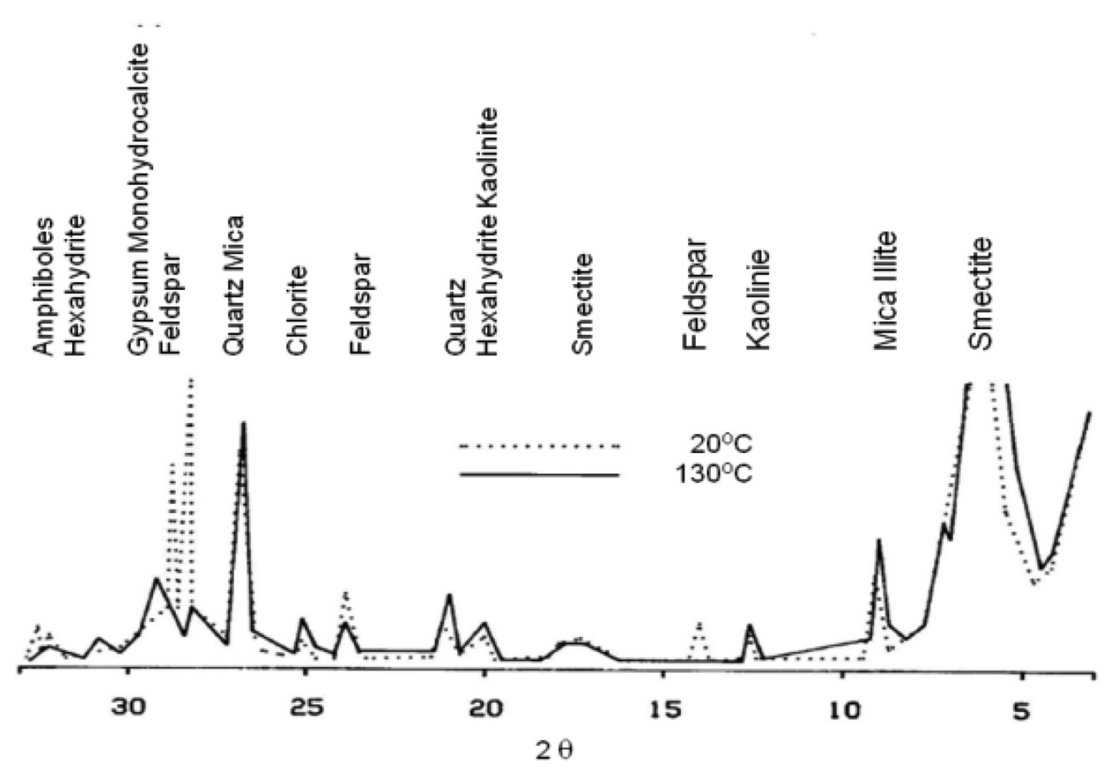

Figure 3: Schematic diffractograms of a montmorillonite-rich reference (MX-80). Sample $\left(20^{\circ} \mathrm{C}\right)$ and of the most heated part of a hydrothermally tested sample for one year $\left(130^{\circ} \mathrm{C}\right)$. Feldspars, amphibole, some of the quartz and smectite disappeared in the hot part [8].
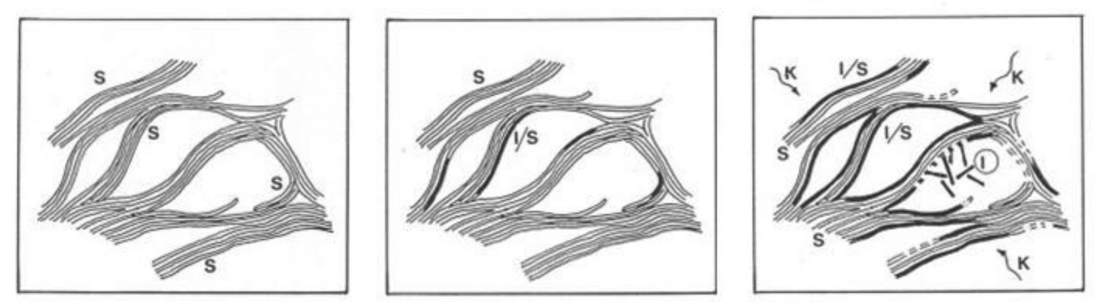

Figure 4: Smectite-to-illite conversion via mixed-layer I/S formation and/or direct. Precipitation of illite. The dark contours represent precipitations of silica and/or illite.

cementation by precipitation of ion complexes at cooling. This is witnessed by the stiffening recorded at several hydrothermal test series [5, 12].

Modelling of the mineralogical changes in montmorillonite according to Grindrod and Takase [8] has been used for determining dissolution and precipitation of phyllosilicates by taking $\mathrm{O}_{10}(\mathrm{OH})_{2}$ as a basic unit. It defines a general formula for smectite (S) and illite (I) as:

$$
\mathrm{X}_{0.35} \mathrm{Mg}_{0.33} \mathrm{Al}_{1.65} \mathrm{Si}_{4} \mathrm{O}_{10}(\mathrm{OH})_{2} \text { and } \mathrm{K}_{0.5-0.75} \mathrm{Al}_{2.5-2.75} \mathrm{Si}_{3.25-3.5} \mathrm{O}_{10}(\mathrm{OH})_{2}
$$

Where $\mathrm{X}$ is the interlamellar absorbed cation (Na) for $\mathrm{Na}$ montmorillonite, $\mathrm{Ca}$ for $\mathrm{Ca}$ montmorillonite etc.

According to the model the rate of the reaction $r$ can be expressed as:

$$
R=\mathrm{A} \exp \left(-E_{a} / \mathrm{RT}\right)\left(K^{+}\right) S^{2}
$$



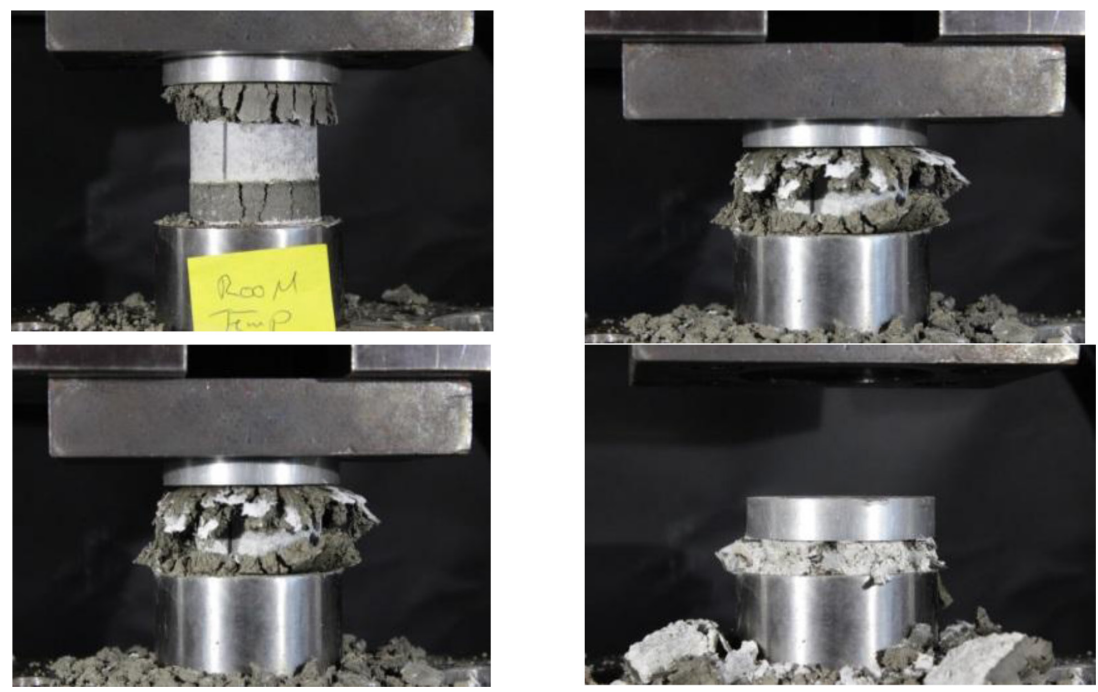

Figure 5: Compression stages showing that initial failure took place in the upper clay sample at $519 \mathrm{kPa}$ pressure, corresponding to a shear strength of about $260 \mathrm{kPa}$ of the clay saturated with distilled water. The concrete remained intact until the pressure was 4.2 $\mathrm{MPa}$ and the total compressive strain had become about 50\% [13].

Where: $A=$ coefficient, $E_{a}=$ activation energy for the conversion of montmorillonite to illite $(\mathrm{S} / \mathrm{I}), \mathrm{R}=$ universal gas constant, $\mathrm{T}=$ absolute temperature, $K^{+}=$potassium concentration in the porewater, and $S=$ specific surface area.

This model shows that silica will be released and transported from the hottest to the coldest part of the clay around the canisters. Thus, assuming linear temperature drop with time back to $25^{\circ} \mathrm{C}$ in 10,000 years, silicification and illitization would be initiated very early and be significant after a few hundred years, the first-mentioned process taking place close to the rock, and the latter occurring in the hottest part $\left(150^{\circ} \mathrm{C}\right)$.

For VDH the high temperature in the waste-bearing part accelerates the rates of illitization. Thus, using eqn (5), one finds that an increase in clay temperature from 100 to $150^{\circ} \mathrm{C}$ speeds up the rate of conversion of montmorillonite to illite considerably: half the entire original content of montmorillonite will be converted to illite about 100 times quicker at the higher temperature than at $100^{\circ} \mathrm{C}$, assuming the activation energy to be $27 \mathrm{kcal} / \mathrm{mole}$ and all other factors being the same. The strongest loss in effective sealing potential will take place in the first 100 years, but the practical importance is rather small since the isolating ability of the clay reaction products is still considerable. Thus, for montmorillonite with a dry density ${ }^{3}$ of $1,600 \mathrm{~kg} / \mathrm{m}^{3}$ converted to pure illite, the hydraulic conductivity will still be acceptably low $(<\mathrm{E}-8 \mathrm{~m} / \mathrm{s}$; Pusch [12]). Complete conversion to non-expandable illite of the dense clay in the supercontainers $\left(2,000 \mathrm{~kg} / \mathrm{m}^{3}\right)$ would take 100,000 years because the controlling mechanism is the very slow diffusive transport of potassium from the surrounding rock [12].

\footnotetext{
${ }^{3}$ Mass of solids divided by total volume
} 


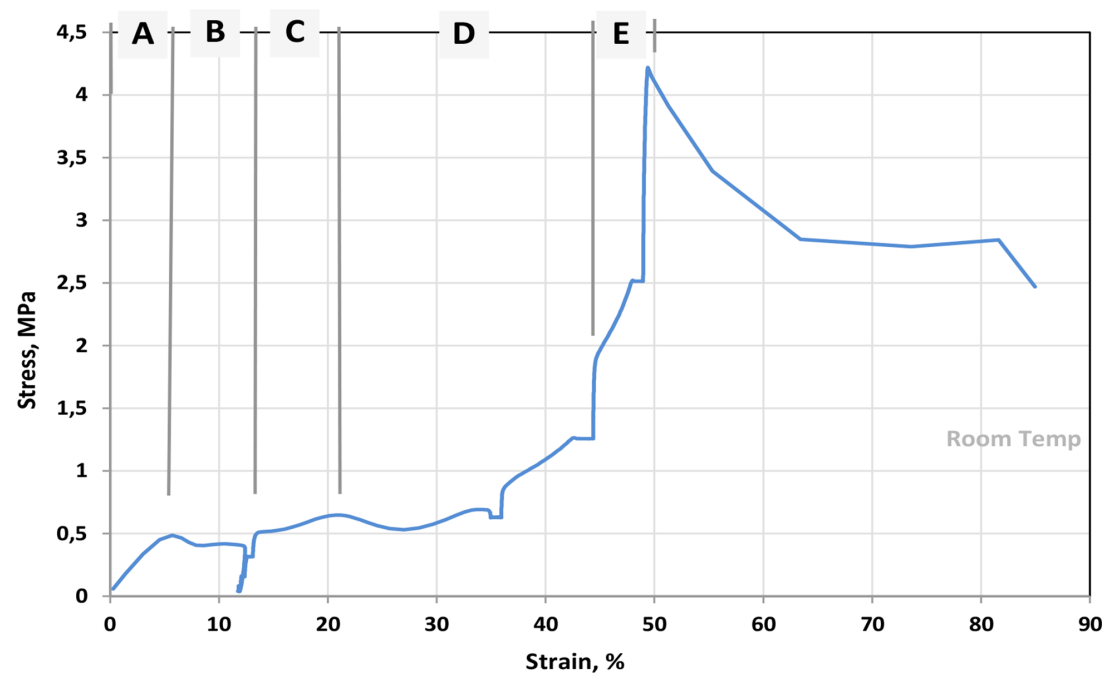

Figure 6: Stress/strain diagram for a compressed combined sample. A-D = compression to failure of clay with distilled water. $\mathrm{E}=$ compression to failure of concrete.

\subsubsection{Reactions between concrete and clay}

Hydrothermal tests of sets of clay samples separated by low-pH concrete with talc as fluidizer have shown very significant strengthening of all the components at compression testing after 8 weeks of curing at 20,100 and $150^{\circ} \mathrm{C}$ temperature in pressurized incubators. Fig. 5 shows successive stages in determining the compressive strength (Fig. 6).

Hydrothermal experiments at up to $150^{\circ} \mathrm{C}$ with a low-pH cement in contact with smectiterich clay have indicated that the major mutual chemical reaction will be cation exchange of initially sorbed $\mathrm{Na}$ in the clay leading to Ca saturation [4, 7]. For $100^{\circ} \mathrm{C}$ temperature, representing the upper $2 \mathrm{~km}$ part of $\mathrm{VDH}$, there will be an increase in compressive strength and stiffness of the clay by approximately $25 \%$ compared to room temperature. For $150^{\circ} \mathrm{C}$, which is valid for the lowermost part of $\mathrm{VDH}$, the same type of stiffening takes place, but the impact is stronger: the compressive strength of the clay and cement is estimated to become $50 \%-$ $100 \%$ higher than at room temperature, making the clay brittle and without expandability. The chemical stability of the clay component is determined by the concentration of $\mathrm{Si}$ in the water.

\section{CONCLUSIONS}

The major conclusions from the study are:

\subsection{Concrete evolution}

Concrete with Portland cement and organic fluidizers will be depleted in Ca and suffer from considerable loss of strength in a thousand year perspective over the entire length of a VDH, but since the amount of cement will be very low (6\%-8\%) and the porosity hence very low, concrete plugs in a VDH will still have sufficient load-bearing capacity. Concrete with a low$\mathrm{pH}$ cement and talc as a fluidizer are expected to be more chemically stable and have a higher mechanical strength than the first-mentioned. 


\subsection{Clay evolution}

In the upper, sealed part of the VDH the temperature will range from about $15^{\circ} \mathrm{C}-60^{\circ} \mathrm{C}$ causing no heat-induced changes of the clay seals, and providing complete tightness directly after installation. Cation exchange from initially $\mathrm{Na}$ to $\mathrm{Ca}$ will increase the hydraulic conductivity, but it will still be sufficiently low $(<\mathrm{E}-11 \mathrm{~m} / \mathrm{s}$; Pusch [8]) for preventing groundwater to flow across and along the deep holes. In the deepest waste-bearing part, where the temperature will be up to $150^{\circ} \mathrm{C}$ in the first $50-100$ years, then successively dropping to about $100^{\circ} \mathrm{C}$, the most obvious effect of the hydrothermal impact is cementation. Conversion to illite will take place, but the associated increase in hydraulic conductivity will not be substantial.

\subsection{Interaction of clay and concrete}

Hydrothermal experiments at up to $150^{\circ} \mathrm{C}$ with a low-pH cement in contact with smectiterich clay have indicated what the mutual impact of concrete and clay seals will be in a VDH $[4,13]$. The major reaction is cation exchange in the clay of initially sorbed Na leading to Ca saturation. For $100^{\circ} \mathrm{C}$ temperature, representing $\mathrm{KBS}-3 \mathrm{H}$ and the upper $2 \mathrm{~km}$ part of $\mathrm{VDH}$, there will be an increase in compressive strength and stiffness of the clay by approximately $25 \%$ compared to room temperature. For $150^{\circ} \mathrm{C}$, valid for the lowermost part of $\mathrm{VDH}$, the same type of stiffening takes place, but the impact is stronger: the compressive strength of the clay and cement is estimated to become 50\%-100\% higher than at room temperature, making the clay brittle and without expandability. The chemical stability of the clay component is determined by the concentration of Si dissolved in the water.

\section{CONCLUSION}

In all parts of a VDH the clay seals are quickly water saturated under the prevailing high water pressure. The ultimate density of the clay blocks will be 1,900 to $2,000 \mathrm{~kg} / \mathrm{m}^{3}$, giving the clay a sufficiently low hydraulic conductivity and an acceptable swelling pressure even in a long-term perspective [8].

The most effective barrier to migration of possibly released radionuclides is the low mobility of the very heavy groundwater at depth.

\section{REFERENCES}

[1] Pusch, R., Ramqvist, G. \& Knutsson, S., Modern techniques for sealing deep cored boreholes. Engineering Geology, 202, pp. 132-142, 2016. http://dx.doi.org/10.1016/j.proeps.2015.08.038

[2] Pusch, R., A technique to delay hydration and maturation of borehole seals of expansive clay. Engineering Geology, 121, pp. 1-6, 2011. http://dx.doi.org/10.1016/j.enggeo.2011.04.017

[3] Yang, T., Pusch, R., Knutsson, S., Liu, X., Lab testing of method for clay isolation of spent reactor fuel in very deep boreholes. In Proceeding World Multidisciplinary Earth Sciences Symposium - WMESS 2015, September 7-11, Prague, Czech Republic, 2015. http://dx.doi.org/10.1016/j.proeps.2015.08.038

[4] Warr, L.N. \& Grathoff, G.H., Sealing of investigation boreholes: Mineralogical and geochemical borehole plug analyses. Technical report, swedish nuclear fuel and waste management co., Ernst-Moritz-Arndt-Universität, Greifswald, Germany, 2010. 
[5] Pusch, R., Warr, L., Grathoff, G., Pourbakhtiar, A., Knutsson, S. \& Mohammed M.H., A talc-based cement-poor concrete for sealing boreholes in rock. Engineering Geology, 5, pp. 251-267, 2013. http://dx.doi.org/10.4236/eng.2013.53036

[6] Pusch, R., Chemical interaction of clay Buffer Materials and concrete. Swedish Nuclear Fuel and Waste Management Co (SKB). Report SFR 82-01, 1982.

[7] Pusch, R., Zwahr, H., Gerber, R. \& Schomburg, J., Interaction of cement and smectite clay - theory and practice. Applied Clay Science, 23, pp. 203-210, 2003. http://dx.doi.org/10.1016/S0169-1317(03)00104-2

[8] Pusch, R., Geological Storage of Radioactive Waste, Springer-Verlag, Berlin, Heidelberg, ISBN: 978-3-540-77332-0, 2008 http://dx.doi.org/10.1007/978-3-540-77333-7

[9] Lindgreen, H., Elemental and structural changes in illite/smectite mixed-layer clay minerals during diagenesis in Kimmeridgian- Volgian (- Ryazanian) clays in the Central Trough, North Sea and the Norwegian-Danish Basin. Bull. Geol. Soc. Denmark, 39, pp. 1-82, 1991.

[10] Gueven, N. \& Huang, W-L., Effects of $\mathrm{Mg}^{2+}$ and $\mathrm{Fe}^{3+}$ substitutions on the crystallization of discrete illite and illite/smectite mixed layers. Dept. Geosciences Texas Tech University, Exxon Production research Co, Houston, Texas, USA, 1990.

[11] Pusch, R., Yong, R.N. \& Nakano, M., Stiffening of smectite buffer clay by hydrothermal effects. Engineering Geology, 110, pp. 21-31, 2010. http://dx.doi.org/10.1016/j.enggeo.2010.07.002

[12] Pusch, R., Bentonite Clay, CRC Press (Taylor \& Francis Group), ISBN 13:978-1-48224343-7, 2015.

[13] Mohammed, M.H., Pusch, R., Al-Ansari, N., Knutsson, S., Emborg, M., Nilsson, M. \& Pourbakhtiar, A., Talc-based concrete for sealing borehole optimized by using particle packing theory. Journal of Civil Engineering and Architecture, 7(4), pp. 440-455, 2013. 